\title{
Subject Status Sequence Number
}

National Cancer Institute

\section{Source}

National Cancer Institute. Subject Status Sequence Number. NCI Thesaurus. Code C117656.

An identifier that describes the relative position of subject status data within a series. 